\title{
Disputed paternity presumption in Burkina Faso: determination of the biological fathers of children using ABO-rhesus/ hemoglobin electrophoresis and STR assays
}

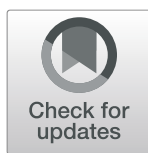

\author{
Missa Millogo ${ }^{1,2}$, Serge Theophile Soubeiga ${ }^{2,3,4^{*}}$ (D), Bapio Valerie Jean Telesphore Bazie ${ }^{2,3,5}$, \\ Theodora Mahoukede Zohoncon ${ }^{2,3,6}$, Abdoul Karim Ouattara ${ }^{2,3}$, Albert Theophane Yonli, ${ }^{2,3}$ and \\ Jacques Simpore $2,3,6$
}

\begin{abstract}
Background: In resource-limited countries, ABO, HLA, MNS, Kells, and hemoglobin electrophoresis are classic tests for the resolution of paternity disputes due to their affordable cost. The limitations of these tests in cases of disputed paternity require the use of Short Tandem Repeats (STR) for their certification. This study aimed to determine the biological fathers of children using ABO-rhesus/hemoglobin electrophoresis and STR assays in Burkina Faso, West Africa.

Results: Of the fourteen trios studied, the ABO-rhesus/hemoglobin electrophoresis analysis revealed ten probable inclusion cases, three exclusion cases, and one undetermined paternity. DNA STR analysis found five inclusions of paternity out of the ten probable inclusions with $\mathrm{ABO}$-rhesus/hemoglobin electrophoresis assay versus nine exclusions of paternity.
\end{abstract}

Conclusion: This study showed that the implementation of the analysis of short tandem repeat is required to resolve increasing disputed filiation cases in Burkina Faso.

Keywords: Paternity, ABO-rhesus, Hemoglobin electrophoresis of Short Tandem Repeat, Burkina Faso, West Africa

\section{Background}

The biological determination of filiations is an old problem. The analysis is based on the genetic polymorphisms of individuals and their Mendelian transmission [1, 2]. Referring to techniques based on blood group determination, some authors showed that in affiliation cases, a combined exclusion chance for non-fathers of $99.995 \%$

\footnotetext{
* Correspondence: theo.soubeiga@gmail.com

${ }^{2}$ Laboratory of Molecular Biology and Genetics (LABIOGENE) of University Joseph Ki-Zerbo, P.O. 03 BOX, 7021 Ouaga 03, Ouagadougou, Burkina Faso ${ }^{3}$ Biomolecular Research Centre Pietro Annigoni (CERBA)), P.O. 01 BOX 364,

Ouagadougou Ouaga 01, Burkina Faso

Full list of author information is available at the end of the article
}

is obtained by the examination of well-established blood group systems [3]. The issues in the use of these methods to include paternity of "alleged fathers" are related to the random transmission of alleles in the general population. The late maturation of antigens is a barrier to the determination of filiation using the $\mathrm{ABO}$ system. Thus, the establishment of parentage, by the current tests such as ABO, HLA, MNS, and Kell, is not accurate, with low exclusion probabilities around 0.17 [4]. Moreover, hemoglobin $(\mathrm{Hb})$ electrophoresis can be used for paternity dispute cases based on the allelic variants between individuals [5, 6]. However, the technique is

\section{Springer Open}

(- The Author(s). 2021 Open Access This article is licensed under a Creative Commons Attribution 4.0 International License, which permits use, sharing, adaptation, distribution and reproduction in any medium or format, as long as you give appropriate credit to the original author(s) and the source, provide a link to the Creative Commons licence, and indicate if changes were made. The images or other third party material in this article are included in the article's Creative Commons licence, unless indicated otherwise in a credit line to the material. If material is not included in the article's Creative Commons licence and your intended use is not permitted by statutory regulation or exceeds the permitted use, you will need to obtain permission directly from the copyright holder. To view a copy of this licence, visit http://creativecommons.org/licenses/by/4.0/. 
limited when there is correspondence between the $\mathrm{Hb}$ genotype of the alleged father-mother and child. Taking these limitations into account, in the context of paternity research, it is necessary to combine several systems [ABO, rhesus, HLA, MNS, Kell, serum systems...] or to use other more efficient systems such as microsatellite genetic analysis, or "short tandem repeats" (STR) [7, 8]. Hemoglobin electrophoresis is complementary to ABOrhesus because the first is for "exclusion" when the latter detected "inclusion".

STR is a polymorphic locus present in all eukaryotic genomes. They generally consisted of tandem matrices of short repeated sequences of 2 to 6 base pairs, and polymorphism occurs when the number of copies of the repeated sequence present at a given STR locus varies between individual chromosomes [9-11]. Hundreds of microsatellites have been studied and some are used as markers for the determination of genetic fingerprints to discriminate or genetically link individuals (families, immigrants, etc.) [12]. They present a wide diversity and can be used in the identification of paternity testing cases $[8,13]$. The application of STRs to the search for parentage in 877 paternity cases had in the past ruled out $35.2 \%$ of cases and found a probability of paternity of $99.9999 \%$ [14]. In Burkina Faso, the justice system is facing strong demands for paternity tests, causes of divorce, and family conflicts. Despite the technical limitations with a high risk of misidentification of the biological father, ABO-rhesus/Hb electrophoresis has been used for a long time to resolve paternity disputed cases in Burkina Faso, because of their affordability and the absence of STR assays. For a deep identification, the present pioneer study aimed to determine the biological fathers of children using the old $\mathrm{ABO}$-rhesus/ $\mathrm{Hb}$ electrophoresis method and STR assays for the first time in Burkina Faso, West Africa.

\section{Methods}

\section{Sample collection}

Fourteen trios (mother-child-alleged father) were involved in the present study. They were referred to the Pietro Annigoni Biomolecular Research Centre for samples (42) collection and paternity tests at the request of the Tribunal de Grande Instance de Ouagadougou. Written informed consent was obtained from participants before blood sample collection on EDTA tube for blood grouping and $\mathrm{Hb}$ electrophoresis and on FTA paper (NucleiCard, Brescia, Italy).

\section{Carrying out blood grouping and hemoglobin electrophoresis}

The determination of the blood and rhesus groups was performed using the Beth-Vincent technique with Anti$\mathrm{A}$, Anti-B, Anti-AB, and Anti-D sera. The determination of the hemoglobin type was performed using the HELENA electrophoresis chain (Helena Biosciences Europe, Queensway South, Gateshead Tyne, and Wea) according to the manufacturer's instructions. Hemolysate was prepared by mixing $1 \mathrm{~V}$ of the whole blood with $3 \mathrm{~V}$ of Helena hemolysis reagent (0.005 M EDTA and 0.01\% potassium cyanide). Electrophoresis was performed at 350 $\mathrm{V}$ for $25 \mathrm{~min}$ in a boric acid/Tris-EDTA buffer ( $\mathrm{pH} 8.4$, ionic strength $=0.035$ ).

\section{Amplification by polymerase chain reaction (PCR)}

PCR amplification was performed using $1.2 \mathrm{~mm}$ of bloodstained disc obtained by a punch on FTA paper previously soaked in blood and containing 5 to $20 \mathrm{ng}$ of DNA. A multiplex PCR amplification of 16 loci of tandem repeat strap (polymorphic STR loci) was performed using the AmpFlSTR ${ }^{\circ}$ identifiler ${ }^{\circ}$ Direct kit (Applied Biosystems, Foster City, CA, USA) according to the manufacturer's instructions. Among the 16 STRs, the Amelogenin marker was included to allow genetic identification of the sex of each subject. The characteristics of the 16 STRs are shown in Table 1. The PCR was performed in $25 \mu \mathrm{L}$ of reaction volume containing 5-20 ng DNA, $12.5 \mu \mathrm{L}$ primers, and $12.5 \mu \mathrm{L}$ Master Mix on the Gene Amp PCR System 9700 thermocycler (Applied Biosystems, USA) according to the following program: initial denaturation at $94^{\circ} \mathrm{C}$ for $11 \mathrm{~min}, 28$ cycles of $9^{\circ} \mathrm{C}$ for $20 \mathrm{~s}, 59^{\circ} \mathrm{C}$ for $3 \mathrm{~min}$, and $72^{\circ} \mathrm{C}$ for $1 \mathrm{~min}$, and final extension at $60^{\circ} \mathrm{C}$ for $25 \mathrm{~min}$.

\section{Capillary electrophoresis}

The amplification fragments obtained were then analyzed on the ABI 3130 Genetic Analyzer (Applied Biosystem, USA) on a 96-well plate containing $1 \mu \mathrm{L}$ of PCR product, $8.7 \mu \mathrm{L}$ of Hi-Di Formamide, and $0.3 \mu \mathrm{L}$ of GeneScan 500 LIZ Size Standard followed by denaturation at $95^{\circ} \mathrm{C}$ for $3 \mathrm{~min}$ and immediate cooling on ice for $3 \mathrm{~min}$. The electrophoresis was performed with PerformanceOptimized Polymer 4 (POP4) with a capillary of $36 \mathrm{~cm}$. After electrophoresis, GeneMapper ID version v3.2.1 software was used to assemble the obtained sequences and compares them to the allele scale to determine the allele types present in each analyzed sample.

\section{Statistical analyses}

The paternity index (PI), which measures the weight of scientific evidence obtained from the paternity test, was calculated for each STR locus using the method described by Eisenberg, 2003. Then, the combined paternity index (CPI) was estimated by multiplying the individual paternity index with the others. The probability of paternity (POP), a conditional probability of knowing whether an alleged father is the biological father of a child, was calculated using the following equation: CPI $x$ 
Table 116 STR loci and alleles with their characteristics

\begin{tabular}{|c|c|c|c|}
\hline Locus & $\begin{array}{l}\text { Location on the } \\
\text { chromosome }\end{array}$ & Included alleles & Fluorochrome \\
\hline D8S1179 & 8 & $8,910,11,12,13,14,15,16,17,18,19$ & 6-FAM \\
\hline D21S11 & $21 q 11.2-q 21$ & $\begin{array}{l}24,24.2,25,26,27,28,28.2,29,29.2,30 \\
30.2,31,31.2,32,32.2,33,33.2,34,34.2 \\
35,35.2,36,37,38\end{array}$ & \\
\hline D7S820 & $7 q 11.21-22$ & $6,7,8,9,10,11,12,13,14,15$ & \\
\hline CSF1PO & $5 q 33.3-34$ & $6,7,8,9,10,11,12,13,14,15$ & \\
\hline D3S1358 & $3 p$ & $12,13,14,15,16,17,18,19$ & $\mathrm{VIC}$ \\
\hline TH01 & $11 \mathrm{p} 15.5$ & $4,5,6,7,8,9,9.3,10,11,13.3$ & \\
\hline D13S317 & $13 q 22-31$ & $8,9,10,11,12,13,14,15$ & \\
\hline D16S539 & 16q24-qter & $5,8,9,10,11,12,13,14,15$ & \\
\hline D2S1338 & $2 q 35-37.1$ & $15,16,17,18,19,20,21,22,23,24,25,26,27,28$ & \\
\hline D19S433 & $19 q 12-13.1$ & $9,10,11,12,12.2,13,13.2,14,14.2,15,15.2,16,16.2,17,17.2$ & NED \\
\hline VWA & 12p12-pter & $11,12,13,14,15,16,17,18,19,20,21,22,23,24$ & \\
\hline TPOX & 2p23-2per & $6,7,8,9,10,11,12,13$ & \\
\hline D18S51 & $18 q 21.3$ & $7,9,10,10.2,11,12,13,13.2,14,14.2,15,16,17,18,19,20,21,22,23,24,25,26,27$ & \\
\hline Amelogenin & $\begin{array}{l}X: p 22.1-22.3 \\
\text { Y: } p 11.2\end{array}$ & $X, Y$ & PET \\
\hline D5S818 & $5 q 21-31$ & $7,8,9,10,11,12,13,14,15,16$ & \\
\hline FGA & $4 q 28$ & $\begin{array}{l}17,18,19,20,21,22,23,24,25,26,26.2,27,28,29,30,30.2,31.2,32.2,33.2,42.2,43.2,44.2 \\
45.2,46.2,47.2,48.2,50.2,51.2\end{array}$ & \\
\hline
\end{tabular}

$0.5 /[\mathrm{CPI} \times 0.5+(1-0.5)]$, the CPI is the combined paternity index and 0.5 is the prior probability [15].

\section{Ethics approval and consent to participate}

This study was approved by the Institutional Ethics Committee of CERBA/LABIOGENE and The Tribunal de Grande Instance de Ouagadougou (Deliberation $\mathrm{N}^{\circ} 2019-19 /$ III-015) and conducted according to the Declaration of Helsinki. Also, written informed consent was obtained before blood collection.

\section{Results}

Inclusion and exclusion by the $\mathrm{ABO} /$ rhesus system and hemoglobin electrophoresis

Of the 14 trios, the $\mathrm{ABO} /$ rhesus system showed only one case of exclusion while $\mathrm{Hb}$ electrophoresis reported two cases of exclusion. The trio affected by the exclusion revealed by the $\mathrm{ABO} /$ rhesus system is different from the other two found by $\mathrm{Hb}$ electrophoresis. Two cases were considered inconclusive because of fetal hemoglobin ( $\mathrm{Hb}$ F) immaturity in children (Table 2).

\section{Inclusion and exclusion according to the STR analysis}

The analysis of the 16 STRs identified the DNA profile of each trio (mother-child-alleged father). These results revealed cases of inclusion and exclusion by comparing the child's alleles with those of both parents and by calculating the PI and POP. Of the 14 trios, 5 alleged fathers (trios $1,3,7,8$, and 13) were included in paternity while 9 (trios 2, 4, 5, 6, 9, 10, 11, 12, and 14) were excluded from paternity. The paternity index ranged from 0 to 37, 072, 170, and 900 and the highest POP was $99.99999999997 \%$ found in trio 3 (Table 3). Figures 1 and 2 show examples of inclusion and exclusion of paternity.

\section{Evaluation of paternity inclusion and exclusion according to the test used}

Comparison of the results using the two methods revealed that 5 alleged fathers (35.71\%) were included of paternity with the analysis of STR as opposed to 10 inclusions (71.43\%) of paternity found with the ABOrhesus/Hb electrophoresis method. But all 5 inclusions reported by analysis of genetic polymorphism of DNA were also found by the ABO-rhesus/Hb electrophoresis method (Table 4). Table 5 compares the inclusion/exclusion results by methods used for each trio case. Eight out of nine exclusions found with STR assay were included using $\mathrm{ABO}$ genotyping. Moreover, 5 inclusions (trios 2, 11, 12, 14) found with $\mathrm{Hb}$ electrophoresis were excluded using STR assay.

\section{Discussion}

To our knowledge, this study is considered the first study in Burkina Faso concerned with the disputed paternity presumption. Here, in addition to the $\mathrm{ABO} /$ 
Table 2 Inclusion and exclusion results according to the ABO-rhesus/hemoglobin electrophoresis

\begin{tabular}{|c|c|c|c|c|c|c|c|}
\hline \multirow[t]{2}{*}{ Trio } & \multicolumn{3}{|c|}{ ABO/rhesus (hemoglobin electrophoresis) } & \multicolumn{3}{|c|}{ Inclusion and exclusion } & \multirow[t]{2}{*}{ Conclusion } \\
\hline & Mother & Child & Alleged father & $\overline{A B O}$ & Rhesus & Hemoglobin electrophoresis & \\
\hline 1 & $B+(A C)$ & $\mathrm{O}+(\mathrm{AA})$ & $A+(A A)$ & Inclusion & Inclusion & Inclusion & Probable inclusion \\
\hline 2 & $A+(A A)$ & $A B+(A A)$ & $B+(A A)$ & Inclusion & Inclusion & Inclusion & Probable inclusion \\
\hline 3 & $B+(A C)$ & $B+(A C)$ & $B-(A A)$ & Inclusion & Inclusion & Inclusion & Probable inclusion \\
\hline 4 & $\mathrm{O}+(\mathrm{AA})$ & $B+(A F)$ & $A+(A A)$ & Exclusion & Inclusion & Inconclusive & Exclusion \\
\hline 5 & $\mathrm{O}+(\mathrm{AA})$ & $B+(A F)$ & $\mathrm{B}+(\mathrm{AS})$ & Inclusion & Inclusion & Inconclusive & Inconclusive \\
\hline 6 & $B+(A C)$ & $B+(A A)$ & $B+(A S)$ & Inclusion & Inclusion & Inclusion & Probable inclusion \\
\hline 7 & $B+(A C)$ & $B+(A A)$ & $\mathrm{B}+(\mathrm{AA})$ & Inclusion & Inclusion & Inclusion & Probable inclusion \\
\hline 8 & $\mathrm{O}+(\mathrm{AA})$ & $B+(A A)$ & $A B+(A A)$ & Inclusion & Inclusion & Inclusion & Probable inclusion \\
\hline 9 & $\mathrm{O}+(\mathrm{AA})$ & $B+(A C)$ & $A B+(A A)$ & Inclusion & Inclusion & Exclusion & Exclusion \\
\hline 10 & $\mathrm{O}+(\mathrm{AA})$ & $A+(A C)$ & $A B+(A A)$ & Inclusion & Inclusion & Exclusion & Exclusion \\
\hline 11 & $B+(A S)$ & $A B+(A A)$ & $A+(A S)$ & Inclusion & Inclusion & Inclusion & Probable inclusion \\
\hline 12 & $A+(A A)$ & $\mathrm{O}+(\mathrm{AA})$ & $A+(A S)$ & Inclusion & Inclusion & Inclusion & Probable inclusion \\
\hline 13 & $A+(A A)$ & $A+(A A)$ & $A B+(A C)$ & Inclusion & Inclusion & Inclusion & Probable inclusion \\
\hline 14 & $A+(A A)$ & $A+(A A)$ & $A+(A A)$ & Inclusion & Inclusion & Inclusion & Probable inclusion \\
\hline
\end{tabular}

rhesus hemoglobin electrophoresis method, we used STR assay for the identification of biological father in disputed paternity cases. The determination of paternity based on blood grouping, the rhesus factor combining $\mathrm{Hb}$ electrophoresis, had identified some limitations related to the profile of $\mathrm{Hb}$ in young infants in trios 4 and 5. This could be explained by the fact that there is still a significant proportion of fetal hemoglobin ( $\mathrm{Hb} \mathrm{F}$ ) in infants due to their very young age [16]. Considering the blood grouping of parents and children, a match discrepancy was observed (trio4). Hemoglobin electrophoresis also showed match discrepancies in trios 9 and 10 because the $\mathrm{Hb}$ of the child $(\mathrm{AC})$ was different from those of the mother (AA) and the presumed father (AA). However, the presumed fathers of these trios were included by $\mathrm{ABO} /$ rhesus. A child inherits one copy of $\mathrm{Hb}$ from the mother and another from the biological father [17]. Based on this principle, the two presumed fathers (9 and 10) were automatically excluded from paternity. $\mathrm{So}$, the $\mathrm{Hb}$ electrophoresis technique had the benefit to identify exclusion cases not detected by the ABO-Rh method. The other benefit of this technique is the possibility to diagnose hemoglobinopathies cases [18-20]. These match discrepancies would make it difficult for

Table 3 Results of the combined paternity index (CPI) and the probability of paternity (POP) in trio cases

\begin{tabular}{|c|c|c|c|c|}
\hline $\mathrm{N}^{\circ}$ & Cases & CPI & POP & Conclusion of paternity \\
\hline 1 & Trio & $3,263,198,110$ & 0.99999999968 & Inclusion \\
\hline 2 & Trio & 0 & 0.00 & Exclusion \\
\hline 3 & Trio & $37,072,170,900$ & 0.99999999997 & Inclusion \\
\hline 4 & Trio & 0 & 0.00 & Exclusion \\
\hline 5 & Trio & 0 & 0.00 & Exclusion \\
\hline 6 & Trio & 0 & 0.00 & Exclusion \\
\hline 7 & Trio & $196,349,727$ & 0.99999999490 & Inclusion \\
\hline 8 & Trio & $12,695,452,599$ & 0.99999999992 & Inclusion \\
\hline 9 & Trio & 0 & 0.00 & Exclusion \\
\hline 10 & Trio & 0 & 0.00 & Exclusion \\
\hline 11 & Trio & 0 & 0.00 & Exclusion \\
\hline 12 & Trio & 0 & 0.00 & Exclusion \\
\hline 13 & Trio & $2,526,793$ & 0.99999996 & Inclusion \\
\hline 14 & Trio & 0 & 0.00 & Exclusion \\
\hline
\end{tabular}

Legend: $C P I$ combined paternity index, $P O P$ probability of paternity 


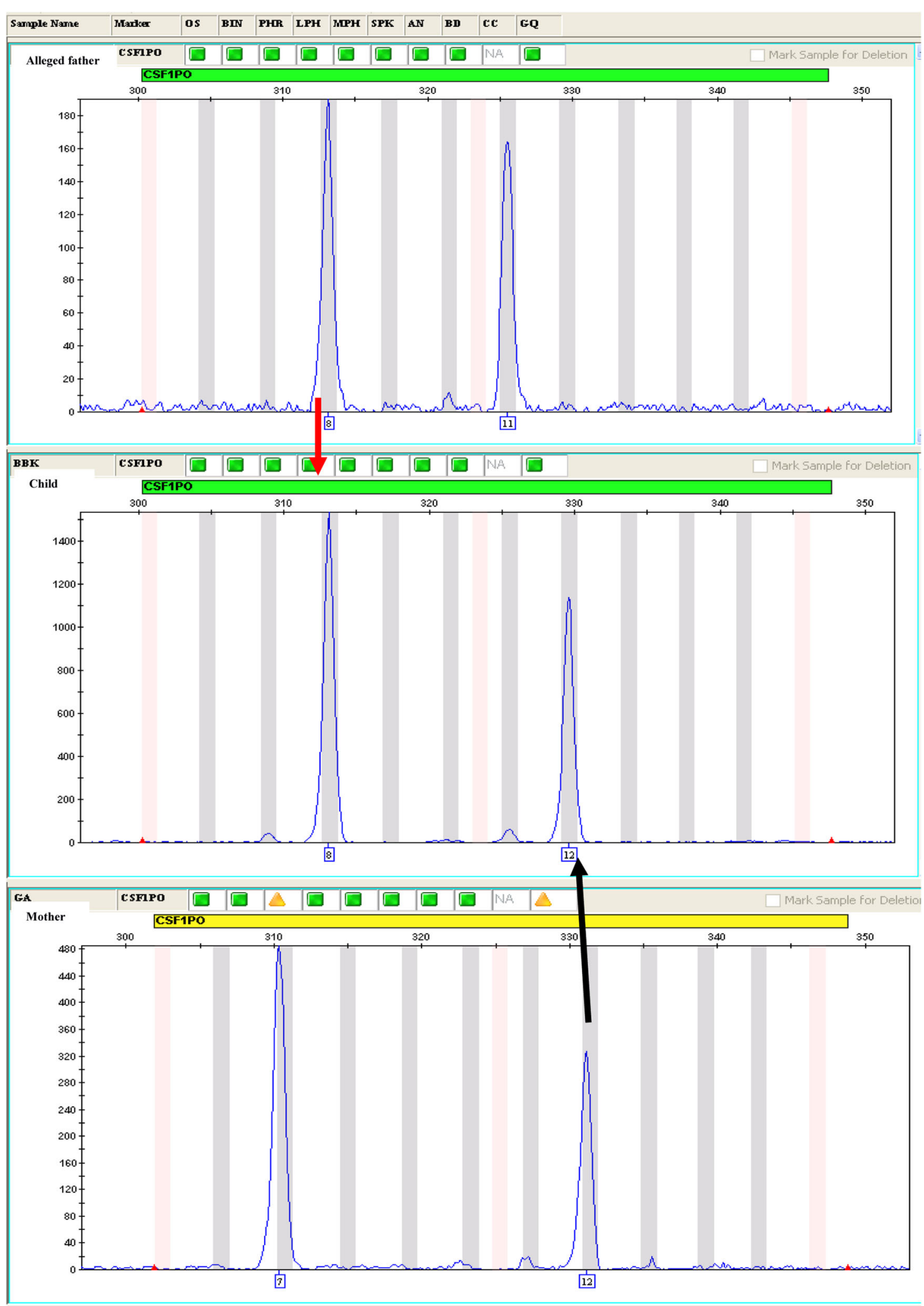

Fig. 1 Inclusion of paternity for the trio 13: example of allele correspondence (allele 8) between alleged father and child for the locus CSF1PO 


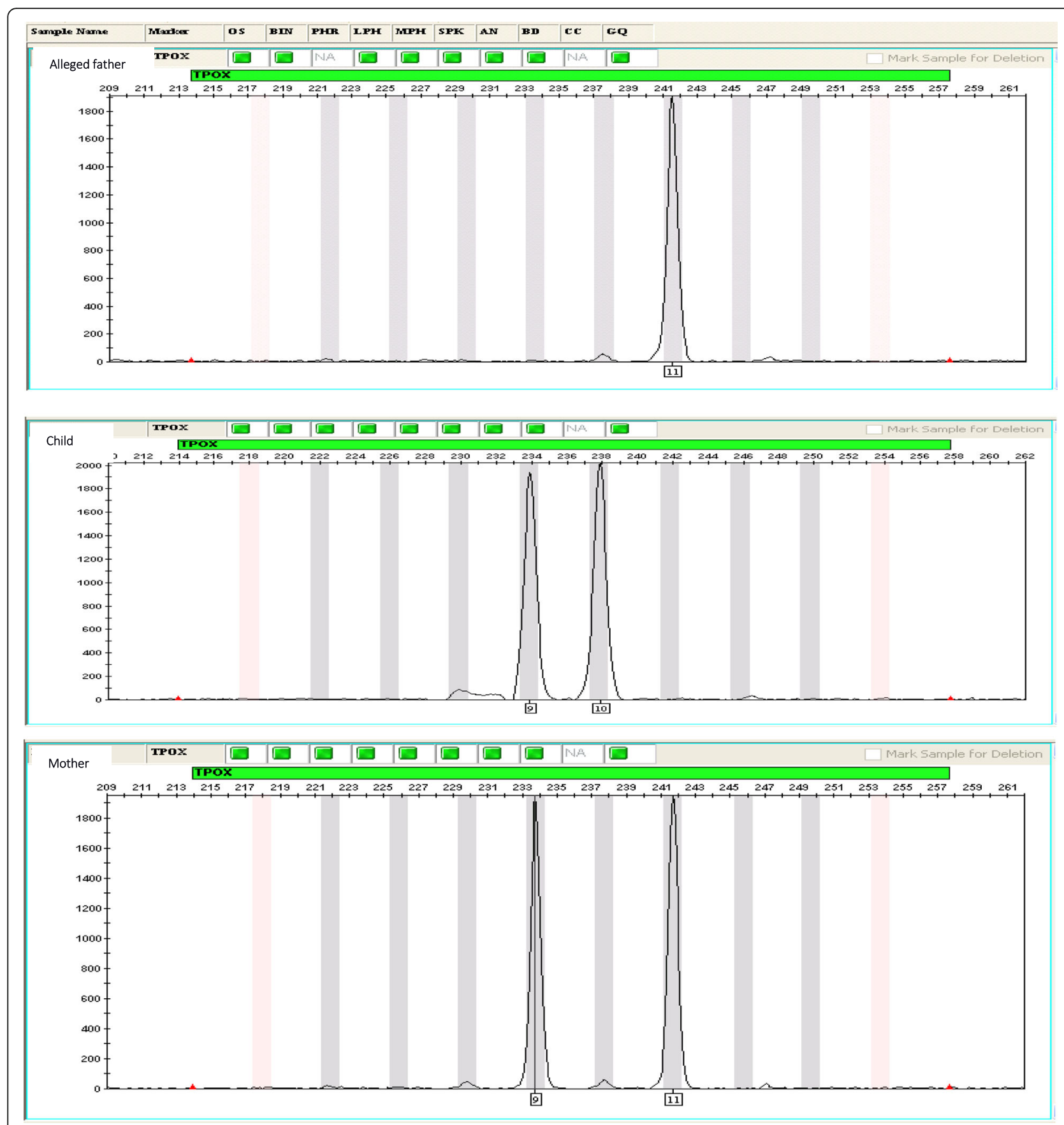

Fig. 2 Exclusion of paternity for the trio 2: example of allele no correspondence between alleged father and child for the locus TPOX

Table 4 Inclusion and exclusion with the ABO-rhesus/ hemoglobin electrophoresis and analysis of STR

\begin{tabular}{lll}
\hline Paternity & ABO-rhesus/Hb electrophoresis & Analysis of STR \\
\hline Inclusion & $10(71.43 \%)$ & $5(35.71 \%)$ \\
Exclusion & $3(21.43 \%)$ & $9(64.29 \%)$ \\
Inconclusive & $1(7.14 \%)$ & $0(0.0 \%)$ \\
\hline
\end{tabular}

Legend: STR Short Tandem Repeat, $\mathrm{Hb}$ hemoglobin the $\mathrm{ABO}$-rhesus and $\mathrm{Hb}$ electrophoresis association to determine paternity. In general, the high frequencies of the ABO system alleles would make it difficult to include the presumed father in a paternity case, but could rather exclude him if, because of his blood type, he did not present the possibility of being the father. From the above, the ABO-rhesus technique associated with $\mathrm{Hb}$ electrophoresis used to determine paternity had limitations. The analysis of STRs consisted of determining the 
Table 5 Comparison of Inclusion and exclusion results by method

\begin{tabular}{lllll}
\hline Trio & ABO & Rhesus & $\begin{array}{l}\text { Hemoglobin } \\
\text { electrophoresis }\end{array}$ & STR assay \\
\hline 1 & Inclusion & Inclusion & Inclusion & Inclusion \\
2 & Inclusion & Inclusion & Inclusion & Exclusion \\
3 & Inclusion & Inclusion & Inclusion & Inclusion \\
4 & Exclusion & Inclusion & Inconclusive & Exclusion \\
5 & Inclusion & Inclusion & Inconclusive & Exclusion \\
6 & Inclusion & Inclusion & Inclusion & Exclusion \\
7 & Inclusion & Inclusion & Inclusion & Inclusion \\
8 & Inclusion & Inclusion & Inclusion & Inclusion \\
9 & Inclusion & Inclusion & Exclusion & Exclusion \\
10 & Inclusion & Inclusion & Exclusion & Exclusion \\
11 & Inclusion & Inclusion & Inclusion & Exclusion \\
12 & Inclusion & Inclusion & Inclusion & Exclusion \\
13 & Inclusion & Inclusion & Inclusion & Inclusion \\
14 & Inclusion & Inclusion & Inclusion & Exclusion \\
\hline
\end{tabular}

genetic markers in the DNA of each trio to compare the alleles of the alleged fathers with those of the children. The Identifiler Direct Kit made it possible to compare 15 alleles between the individuals in each trio. The genetic analysis of the fourteen paternity search trios comprising mother, child, and alleged father revealed $64.29 \%$ of cases of exclusion compared to $21.43 \%$ with ABOrhesus associated with $\mathrm{Hb}$ electrophoresis. This trend was consistent with the studies conducted by Souiden et al., 2007 [15]. The determination of STRs would correct inclusion and exclusion errors induced by the ABOrhesus technique associated with $\mathrm{Hb}$ electrophoresis. The ABO-rhesus system is easily suited to the search for the exclusion of paternity. For example, in trio 4, the mother had group $\mathrm{O}+$, the child had group $\mathrm{B}+$ and the alleged father had group $\mathrm{A}+$. In this case, paternity was excluded with certainty and without recourse to other systems to confirm the result. Similarly, the rhesus system alone could reveal an exclusion, as is the case for example for an O- mother, O+ child, and O- father [16]. But in some cases, such as mother $\mathrm{O}_{+}$, child $\mathrm{A} 1$, father $\mathrm{O}+$, and if the $\mathrm{ABO}$ system is the only exclusion system, paternity is excluded only if it can be shown that one of the parents does not have the Bombay phenotype [21]. On the other hand, the immaturity of antigens in all newborns should be considered; for example, in the following example: mother $\mathrm{O}$, child $\mathrm{A} 2$, father $\mathrm{A} 1 \mathrm{~B}$, the child's blood type should be checked a few months later before reporting an exclusion, as this could be a delay in the development of the A1 antigen. For example, in the case of trios 4 and 5 , the determination of paternity by $\mathrm{Hb}$ electrophoresis was uncertain because children had fetal hemoglobin. In addition, the $\mathrm{Hb}$ electrophoresis technique cannot affirm with certainty the biological father because there can be a match of the $\mathrm{Hb}$ when comparing the $\mathrm{Hb}$ of the trios (mother-child-father) without the presumed father being the biological father. Taking all these limitations into account, in the context of a paternity search, it is necessary to combine several systems (ABO, rhesus, HLA, MNS, Kell, serum systems...) $[4,22]$ or to use other systems such as STR genetic analysis [7]. In this study, STRs solved all the cases studied, as it was based on DNA polymorphism analysis for the identification of an individual. Based on the Bayesian probability law, we determined the PI and the CPI. These PIs maked it possible to determine the probability of paternity of an alleged father "to be" or "not to be" the biological father of a child. The results of this study showed a CPI of more than 100 million, unlike a study conducted in Egypt which found a CPI of more than 1 million [23]. The CPI can be high depending on whether the PI calculated from the allele frequencies is high or low. In the ABO system, three alleles are possible and therefore six possible genotypes are present in the human population. In contrast, STR multiplex markers produce a greater number of possible genotypes, as many alleles are present for each STR locus. Thus, although the ABO-rhesus/Hb electrophoresis is useful for excluding a person from paternity, this technique cannot be used to declare a truth inclusion of paternity. The conclusion of paternity from this technique is "Exclusion" or "probable inclusion." The term "probable inclusion" means that there is a possibility of inclusion of paternity, but this situation needs reliable techniques to confirm. In paternity tests, the results of the probability of filiation would be either $0 \%$ to exclude someone in situations of paternity, siblings, etc., as the biological parent of a child or the same filiation or at least $99 \%$ to confirm someone as the biological parent. Legally, a $99 \%$ or greater probability of a biological relationship is considered proof of paternity $[23,24]$. The inclusion of paternity comes from the fact that one of the child's alleles is identical to one of the alleles of the alleged father for all the markers studied. While the exclusion is explained by the fact that the child did not receive any allele from the alleged father for one or more STR markers. Our results with STR assays were similar to those conducted in Egypt where STR assay was used [23]. In Poland, analysis of results obtained between 1966 and 2014 from paternity testing revealed a percentage of exclusions of $31 \%$ using serological tests (ABO, MNSs, Rh factors, Kell, Duffy, Kidd, white blood cells (HLA), serum proteins), 18\% using RFLP tests and 20\% using STR assay [24]. Another study in Germany using $\mathrm{ABO}$ genotyping by PCR-SSP and $\mathrm{ABO}$ grouping revealed that in 60 paternity trios with confirmed paternity of the alleged father based on STR analysis both 
paternity likelihood and power of exclusion of the $\mathrm{ABO}$ genotype was significantly higher than of the $A B O$ phenotype. In 12 of 35 exclusion cases (34.3\%) the $A B O$ genotype also excluded the alleged father, whereas the $\mathrm{ABO}$ phenotype excluded the alleged father only in 7 cases (20\%) [25]. As demonstrated in this study, the results of paternity tests were better when using STR analysis compared to serological tests. Every individual in the world can be identified at the molecular level based on an extremely greater level of polymorphism in the sequence of DNA which is inherited from biological parents and is identical in every cell of the body $[26,27]$. In inclusion cases, the child shares the length of each STR loci with his parents because each biological parent shares 23 chromosomes for their child and in exclusion cases, the child's length of STR loci differs between the father and mother [28]. In this study, genetic amplification of STRs excluded 9 presumed fathers and identified 5 others as the biological fathers of the children. STR markers provide sufficient discriminatory power to exclude or include an alleged father in contested paternity cases. Unlike ABO-rhesus/Hb electrophoresis techniques which are based on the agglutination of red blood cells and hemoglobin, the STR technique determines the genetic profile of the DNA which contains the genetic information that is unique to each individual [29]. Because of the limitations of $\mathrm{ABO}-\mathrm{Rhesus} / \mathrm{Hb}$ electrophoresis, the PCR technique became the standard process for DNA paternity testing because PCR technology allows amplifying a very small quantity of DNA to increase the amount of DNA up to billions of copies of the same DNA for testing and analysis [28, 30]. Furthermore, STR assays can be used to establish genetic affinity between populations [31]. In this study, the allele frequencies of the African American population provided in the kit's user manual were used to calculate the paternity index because there are no great genetic variations between this population and West Africans [32]. Some studies were done in African countries to determine alleles frequencies [33, 34]. Moreover, the STR analysis can be used in forensic investigations. Additionally, it would be more appropriate to carry out a study to determine the allelic frequencies of the 16 STRs specific to the population of Burkina Faso.

\section{Conclusion}

In Burkina Faso, ABO-rhesus/hemoglobin electrophoresis tests have long been used for paternity exclusion. Because of the limitations of these conventional tests, STR analysis has become the reference technique not only for parentage testing but also for forensic analysis.

\section{Abbreviations}

CPI. Combined paternity index: DNA: Deoxyribonucleic: HbF: Fetal hemoglobin; PCR: Polymerase chain reaction; PI: Paternity index;
POP: Probability of paternity; POP4: Performance-optimized polymer 4; STR: Short tandem repeat

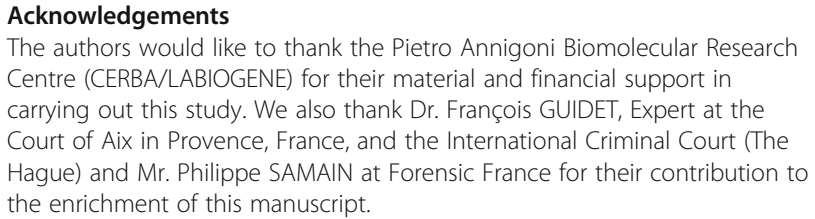

\section{Authors' contributions}

MM and STS analyzed the data and interpreted result. STS, BVJTB, and AKO drafted the manuscript. TMZ participated in the data collection and interpretation. MM, AKO, STS, BVJTB, and JS revised the manuscripts. JS designed the study. The authors read and approved the final manuscript

\section{Funding}

This research did not receive any specific grant from funding agencies in the public, commercial, or not-for-profit sectors.

\section{Availability of data and materials}

Not applicable

\section{Declarations}

Ethics approval and consent to participate

This study was approved by the Institutional Ethics Committee of CERBA LABIOGENE and The Tribunal de Grande Instance de Ouagadougou

(Deliberation N²019-19/III-015) and conducted according to the Declaration of Helsinki. Also, written informed consent was obtained before blood collection.

Consent for publication

Not applicable

\section{Competing interests}

The authors declare that they have no competing interests.

\section{Author details}

${ }^{1}$ Direction of Scientific and Technical Police, Ouagadougou, Burkina Faso. ${ }^{2}$ Laboratory of Molecular Biology and Genetics (LABIOGENE) of University Joseph Ki-Zerbo, P.O. 03 BOX, 7021 Ouaga 03, Ouagadougou, Burkina Faso. ${ }^{3}$ Biomolecular Research Centre Pietro Annigoni (CERBA)), P.O. 01 BOX 364, Ouagadougou Ouaga 01, Burkina Faso. ${ }^{4}$ Research Institute of Health Sciences (IRSS)), P.O. 03. BOX 7192, Ouagadougou Ouaga 03, Burkina Faso. ${ }^{5}$ Research Institute of Applied and Technical Sciences (IRSAT)), P.O. 03 BOX 7047, Ouagadougou Ouaga 03, Burkina Faso. 'University of Saint Thomas d'Aquin (USTA)), P.O. 06 BOX 10212, Ouagadougou Ouaga 06, Burkina Faso.

Received: 26 March 2021 Accepted: 30 July 2021

Published online: 30 August 2021

\section{References}

1. Wenk RE (2004) Testing for parentage and kinship. Curr Opin Hematol 11(5): 357-361. https://doi.org/10.1097/01.moh.0000137914.80855.8a

2. de Mazancourt P, Pfitzinger H (2005) DNA and paternity testing. Gynecol Obstet Fertil 33(7-8):461-463

3. Spielmann W, Kühnl P (1983) Blood group expert evaluation: relation between the extent of testing and the reliability of paternity determination. Reflections on revision and guidelines. J Legal Med 90(1):35-44. https://doi. org/10.1007/BF01886065

4. Salmon C, Cartron J, Rouger P (1991) Paternité: les groupes sanguins chez I'Homme. Masson ed, Paris

5. Szuberski J, Oliveira J, Hoyer JD (2012) A comprehensive analysis of hemoglobin variants by high-performance liquid chromatography (HPLC). Int J Lab Hematol 34(6):594-604. https://doi.org/10.1111/j.1751-553X.2012. 01440.x

6. Riou J, Szuberski J, Godart C, Wajcman H, Oliveira JL, Hoyer JD, BardakdjianMichau J (2018) Precision of CAPILLARYS 2 for the detection of hemoglobin 
variants based on their migration positions. Am J Clin Pathol 149(2):172180. https://doi.org/10.1093/ajcp/aqx148

7. Schlenk J, Seidl S, Braunschweiger G, Betz P, Lederer T (2004) Development of a 13-locus PCR multiplex system for paternity testing. Int J Legal Med 118(1):55-61. https://doi.org/10.1007/s00414-003-0420-5

8. Burguete-Argueta N, Martinez De la Cruz B, Camacho-Mejorado R, Santana C, Noris G, Lopez-Bayghen E et al (2016) Forensic-paternity effectiveness and genetics population analysis of six non-CODIS mini-STR loci (D1S1656, D2S441, D6S1043, D10S1248, D12S391, D22S1045) and SE33 in Mestizo and Amerindian populations from Mexico. Ann Hum Biol 43(6):563-571. https:// doi.org/10.3109/03014460.2015.1127424

9. Thomson JA, Pilotti V, Stevens P, Ayres KL, Debenham PG (1999) Validation of short tandem repeat analysis for the investigation of cases of disputed paternity. Forensic Sci Int 100(1-2):1-16. https://doi.org/10.1016/S0379-073 8(98)00199-6

10. Butler JM (2011) Forensic DNA testing. Cold Spring Harb Protoc 12:14381450

11. Li L, Zhao SM, Zhang SH, Li CT, Liu Y, Lin Y, Liu JH (2012) Typing and polymorphism analysis of 16 STR loci on X chromosome. Fa Yi Xue Za Zhi 28(1):36-40 3

12. Amankwaa AO (2019) Towards a reformed policy for immigrant DNA tests, a commentary. J Forensic Legal Med 66:117-119. https://doi.org/10.1016/j. jflm.2019.06.016

13. Gao JS, Ye Y, Hou YP (2017) Application of SNP-STR Composed by D18S51 and Three SNPs of Its Flanking Region in Paternity Testing. Fa Yi Xue Za Zhi 33(7):607-610

14. Van Huffel V, Rouger P (1999) DNA polymorphism applied to paternity testing. Analysis of 877 cases. Transfus Clin Biol 6(4):236-244. https://doi. org/10.1016/s1246-7820(99)80034-2

15. Eisenberg AJ. Parentage statistics strength of genetic evidence in parentage testing. 2003, https://www.promega.com/-/media/files/resources/ conference-proceedings/ishi-15/parentage-and-mixture-statistics workshop/ introductiontoparentagestatistics.pdf?la=en; (Accessed 25 May 2019).

16. Souiden Y, Chaieb K, Romdhani M, Mahdouani K (2007) Contribution of the genetic fingerprintings compared to grouping $\mathrm{ABO} /$ Rhesus technique in the expertise of filiation. Ann Biol Clin (Paris) 65(6):663-670

17. Hasan MN, Fraiwan A, An R, Alapan Y, Ung R, Akkus A, Xu JZ, Rezac AJ, Kocmich NJ, Creary MS, Oginni T, Olanipekun GM, Hassan-Hanga F, Jibir BW, Gambo S, Verma AK, Bharti PK, Riolueang S, Ngimhung T, Suksangpleng T, Thota P, Werner G, Shanmugam R, Das A, Viprakasit V, Piccone CM, Little JA, Obaro SK, Gurkan UA (2020) Based microchip electrophoresis for point-ofcare hemoglobin testing. Analyst 145(7):2525-2542. https://doi.org/10.1039/ C9AN02250C

18. Caboot JB, Allen JL (2014) Hypoxemia in sickle cell disease: significance and management. Paediatr Respir Rev 15(1):17-23. https://doi.org/10.1016/j. prrv.2013.12.004

19. Obaro SK, Iroh Tam PY (2016) Preventing Infections in sickle cell disease: the unfinished business. Pediatr Blood Cancer 63(5):781-785. https://doi.org/10.1 002/pbc.25911

20. Katamea T, Mjumbe CK, Omoy MN, Bafwafwa D, Ngombe M, Kasongo L et al (2020) Neonatal screening for lubumbashi drepacytosis: feasibility and suitable performance. Open Access Library Journal 7(3):1-12

21. Balgir RS (2005) Detection of a rare blood group "Bombay (Oh) Phenotype" among the Kutia Kondh Primitive Tribe of Orissa, India. Int J Hum Genet 5(3):193-198. https://doi.org/10.1080/09723757.2005.11885925

22. Tongio MM, Dormoy A (1997) HLA genotyping: indications and limits. Transfus Clin Biol 5:6-12

23. El-Alfy SH, El-Hafez AFA (2012) Paternity testing and forensic DNA typing by multiplex STR analysis using ABI PRISM 310 Genetic Analyzer. J Genet Eng Biotechnol 10(1):101-112. https://doi.org/10.1016/j.jgeb.2012.05.001

24. Karpiewska A, Kowalczyk E, Dobosz T (2017) Paternity testing at the Department of Forensic Medicine of Wroclaw Medical University (Poland). Legal Med 26:18-24. https://doi.org/10.1016/j.legalmed.2017.02.002

25. Bugert $P$, Rink $G$, Kemp K, Klüter $H$ (2012) Blood group $A B O$ genotyping in paternity testing. Transfus Med Hemother 39(3):182-186. https://doi.org/1 $0.1159 / 000339235$

26. Mishra A, Sathyan S (2016) DNA Fingerprinting in disputed paternity. Med Phoenix 1(1):44-46

27. Asela PRM, Clarencia RD (2019) A paternity case based on short tandem repeat (str) using DNA finger printing technology. Int J Dev Res 9(12): 32230-32237
28. Essam K, Mona H, Diab AA (2014) Role of DNA in Paternity Testing. J Forensic Sci \& Criminal Inves 14(2):555882

29. De Kock AA, Kloppers JJ (2021) The impact of motherless paternity testing in a South African population. Afr Health Sci 21(1):379-384. https://doi.org/1 0.4314/ahs.v21i1.48

30. Thomsen AR, Hallenberg C, Simonsen BT, Langkjær RB, Morling N (2009) A report of the 2002-2008 paternity testing workshops of the English-speaking working group of the International Society for Forensic Genetics. Forensic Sci Int Genet 3(4):214-221. https://doi.org/10.1016/j. fsigen.2009.01.016

31. Zeye MMJ, Li J, Ouedraogo SY, Zha L, Simpore J, Jifeng C (2021) Population data and genetic structure analysis based on 29 Y-STR loci among the ethnolinguistic groups in Burkina Faso. Int J Legal Med. https://doi.org/10.1 007/s00414-021-02544-9

32. Bryc K, Auton A, Nelson MR, Oksenberg JR, Hauser SL, Williams S, Froment A, Bodo JM, Wambebe C, Tishkoff SA, Bustamante CD (2010) Genome-wide patterns of population structure and admixture in West Africans and African Americans. Proc Natl Acad Sci U S A 107(2):786-791. https://doi.org/10.1 073/pnas.0909559107

33. Rosa A, Ornelas C, Brehm A, Villems R (2006) Population data on 11 Ychromosome STRs from Guiné-Bissau. Forensic Sci Int 157(2-3):210-217. https://doi.org/10.1016/j.forsciint.2005.04.005

34. Semo AC, Carvalho MR, Bogas V, Serra A, Lopes V, Brito P, Sá FB, Porto MJ, Gonçalves IMT, Corte-Real F (2017) Allelic frequencies of 15 autosomal STRs from two main population groups (Makua and Changana) in Mozambique. Forensic Sci Int Genet Suppl Ser 6:e286-e2e8. https://doi.org/10.1016/j. fsigss.2017.09.139

\section{Publisher's Note}

Springer Nature remains neutral with regard to jurisdictional claims in published maps and institutional affiliations.

\section{Submit your manuscript to a SpringerOpen ${ }^{\circ}$ journal and benefit from:}

- Convenient online submission

- Rigorous peer review

- Open access: articles freely available online

High visibility within the field

- Retaining the copyright to your article

Submit your next manuscript at $\boldsymbol{\nabla}$ springeropen.com 